\title{
Penerapan Teknik Mind Maps dalam Meningkatkan Keterampilan Menulis
}

\author{
Yusrumaida* $^{*}$ \\ Jurusan Pendidikan Bahasa dan Sastra Inggris Fakultas Bahasa dan Seni, Universitas Pendidikan Ganesha, Singaraja Indonesia
}

\section{A R T I C L E I N F O}

Article history:

Received 19 May 2018

Received in revised form 25 June 2018

Accepted 10 July 2018

Available online 25 August

2018

Kata Kunci:

teknik mind maps,

keterampilan menulis, SMP

N 2 Singaraja

Keywords:

mind mapping technique, writing competency, SMP N

2 Singaraja

\begin{abstract}
A B S T R A K
Penelitian ini bertujuan untuk meningkatkan keterampilan menulis pada peserta didik kelas VIII SMP Negeri 2 Singaraja melalui teknik mind maps. Penelitian ini adalah penelitian tindakan kelas yang dilaksanakan dalam dua siklus, yang terdiri dari rencana tindakan, pelaksanaan tindakan, observasi atau evaluasi dan refleksi. Subjek penelitian ini adalah siswa kelas VIII-5 SMP Negeri 2 Singaraja, berjumlah 37 orang dengan rincian 14 orang putra dan 23 orang putri. Data dianalisis menggunakan statistik deskriptif. Hasil analisis data ratarata nilai keterampilan menulis siklus I yaitu sebesar 65 dan rata-rata nilai keterampilan menulis siklus II yaitu sebesar 80 . Dari data hasil belajar tersebut dapat dikatakan bahwa hasil belajar keterampilan menulis pada siklus I ke siklus II mengalami peningkatan sebesar 15. Berdasarkan hasil analisis data dan pembahasan dapat disimpulkan bahwa hasil keterampilan menulis meningkat melalui penggunaan teknik mind maps pada siswa kelas VIII-5 SMP Negeri 2 Singaraja. Disarankan kepada guru bahasa Inggris untuk mengaplikasikan teknik mind maps karena dapat meningkatkan hasil keterampilan menulis.
\end{abstract}

\section{A B S T R A C T}

This study aims at improving students' writing competency in class VIII SMP Negeri 2 Singaraja through the use of mind mapping technique. It is a classroom action research with two cycles, involving planning, implementation, observation or evaluation, and reflection. The subject of this study was 37 students involving 14 boys and 23 girls in class VIII SMP Negeri 2 Singaraja. The data were analyzed by using statistic descriptive analysis. The result of the analysis showed that the mean score of students' writing competency in cycle I was 65 and the mean score in cycle II was 80 . It indicated that the writing competency achievement from cycle I to cycle II improved 15 points. Based on the data analysis and the discussion, it can be concluded that students' writing competency improves through the use of mind mapping technique in class VIII-5 SMP Negeri 2 Singaraja. It is also suggested for the English teachers to implement mind mapping technique to improve students' writing competency. 


\section{Pendahuluan}

Didalam Kurikulum 2013 peserta didik dituntut untuk mampu menyusun berbagai jenis teks lisan dan tulis, sangat pendek dan sederhana, dengan memperhatikan fungsi sosial, struktur teks, dan unsur kebahasaan, secara benar dan sesuai konteks. Namun pada kenyataannya, sebagian besar peserta didik menganggap bahwa menulis itu sulit dan peserta didik juga masih sulit dalam menemukan dan menuangkan ide mereka ketika menulis. Pembelajaran menulis khususnya dalam bahasa Inggris di Kelas VIII SMP Negeri 2 Singaraja biasanya dilakukan dengan menggunakan teknik ceramah, dan buku teks sebagai media pembelajaran. Tetapi hasil yang didapat tidak sesuai dengan yang diharapkan. Hal ini dapat dilihat melalui nilai rata-rata peserta didik cenderung berada dibawah standar KKM (75) yang dibuktikan melalui nilai pree test peserta didik.

Dari data tersebut diperoleh 28 peserta didik kelas VIII5 mendapat nilai dibawah standar KKM dan 9 peserta didik mendapat nilai sesuai KKM atau lebih tinggi dari standar KKM pada saat dilakukan pree test. Pada nilai ulanga harian peserta didik kelas VIIIA juga menunjukkan bahwa sebagian besar peserta didik mendapat nilai dibawah standar KKM yaitu sebanyak 29 dari 37 peserta didik. Data ini menunjukkan bahwa kemampuan siswa dalam menulis teks rendah.

Selain melihat hasil pree test dan ulangan harian peserta didik, penulis juaga melakuakan interview informal terhadap guru bidang studi Bahasa Inggris dan peserta didik di Kelas VIII5 SMP Negeri 2 Singaraja pada tanggal 12 September 2017 tentang kemampuan peserta didik dalam menulis, 27 orang peserta didik menganggap bahwa menulis itu sulit. Hasil interview juga menemukan lima masalah besar yang dihadapi peserta didik dalam proses pembelajaran, diantaranya; peserta didik tidak tahu bagaimana menuangkan ide mereka kedalam tulisan melalui topik atau judul yang telah diberiklan, terlebih mereka tidak tahu bagaimana cara mengembangkan ide mereka hal ini dikareanakan peserta didik kekurangan kosakata dalam menulis, selebihnya peserta didik merasa bosan saat mereka belajar karena media dan metode yang digunakan tidak menarik, peserta didik tidak mampu menggunakan tata bahasa yang baik sesuai dengan struktur kebahasaan, hal ini mengacu kepada penggunaan tenses, yang mana merupakan salah satu unsur kebahasaan yang digunakan dalam penyusunan kalimat dengan memperhatikan konteks waktu dan penggunaannya. Dalam hal ini penulis fokus pada masalah utama yang yaitu kemampuan siswa dalam mengembangkan ide mereka ketika menulis sebuah teks, karena dari hasil interview 25 orang peserta didik paling sering mengalami masalah dalam mengembangkan ide mereka ketika menulis.

Dari permasalahan diatas, dapat dilihat bahwa adanya korelasi antara rendahnya kemampuan siswa dalam menulis dan cara guru mengajar serta kemampuan dan motivasi siswa yang rendah. Hal ini tentu menjadi masalah yang harus dipikirkan jalan keluarnya oleh seorang guru. Untuk itu, sebagai upaya penyelesaian masalah guru perlu melakukan perbaikan yang benar, yakni dengan penelitian tindakan kelas. Penelitian tindakan kelas ini tidak semata bermanfaat untuk penyelesaian masalah didalam kelas. Hasil penelitian ini juga bermanfaat sebagai syarat kenaikan pangkat bagi guru PNS, karena PTK merupakan wujud dari pengembangan keprofesian guru pada bidang publikasi ilmiah ( Peraturan Bersama Menteri Pendidikan Nasional dan kepala Badan kepegawaian Negara No. 14 Thaun 2010).

Salah satu cara menyelesaikan permasalahan rendahnya kemampuan siswa dalam menulis sebuah teks yaitu dengan menggunakan salah satu teknik pembelajaran cooperative yaitu Mind Maps. Peneliti tertarik menggunakan teknik ini dikarenakan Mind Maps dikatakan dapat digunakan untuk mengorganisasikan ide-ide yang muncul dan bisa menjadi panduan untuk menulis. Selain itu, mind maps menfasilitasi siswa untuk menghubungkan antara ide dan konsep untuk menggali informasi mudah sehingga mampu meningkatkan ketrampilan menulis siswa. Pernyataan ini didukung oleh Tony Buzan , (2008:4) yang menyatakan bahwa Mind Maps adalah cara mengembangkan kegiatan berpikir ke segala arah, menangkap berbagai pikiran dalam berbagai sudut. Mind Maps mengembangkan cara berpikir divergen dan berpikir kreatif. Mind Maps yang sering kita sebut dengan peta konsep adalah alat berpikir organisasional yang sangat hebat yang juga merupakan cara termudah untuk menempatkan informasi ke dalam otak dan mengambil informasi itu ketika dibutuhkan.

Mind Mapping adalah catatan yang tidak monoton, terdapat unsur seni kreatif yang dibuat dari sebuah gagasan yang mengkaitkan suatutopik utama ke sub topik sebagai cabangnya, sehingga dapat memudahan siswa dalam mengingat semua yang telah dipelajari. Yang mana "metode mencatat yang baik harus membantu kita mengingat perkataan dan bacaan, meningkatkan pemahaman terhadap materi, membantu mengorganisasi materi, dan memberikan wawasan baru (Yosefa, 2013).

Penelitian tindakan kelas dengan menggunakan teknik Mind Maps untuk meningkatkan kemampuan peserta didik dalam menulis teks deskripsi belum pernah dilakukan di Kelas VII SMP Negeri 2 Singaraja, namun penelitian sejenis pernah dilakukan oleh Handayani N (2015) dengan judul "The 
Implementation of Mind Maps in Improving Writing Skill of the Tenth Grade Students of SMA PGRI 2 Denpasar in Academic Year 2014/2015", dimana hasil penelitiannya menunjukkan peningkatan yang berarti yang dilihat dari peningkatan skor rata-rata peserta didik, sehingga dapat disimpulkan bahwa ketrampilan menulis siswa dalam menulis teks deskripsi dapat meningkat melalui pengaplikasian teknik Mind Maps. Hasil penelitian lain yang relevan juga dilakukan oleh Komang Dian Puspita Candra (2013) dengan judul "Peningkatan Kemampuan Menulis Karangan Deskripsi Melalui Kombinasi Mind Mapping dan Facebook Community Siswa Kelas X SMAK Anugrah Global Turism Denpasar" yang juga berhasil menggunakan teknik Mind Maps untuk meningkatkan ketrampilan menulis.

Mengacu kepada beberapa penelitian sebelumnya yang telah berhasil menggunakan teknik Mind Maps untuk meningkatkan kemampuan menulis pada peserta didik, untuk itu penulis sangat yakin untuk mengangkat judul "Penerapan Teknik Mind Maps dalam Meningkatkan Keterampilan Menulis pada Siswa Kelas VIII-5 SMP Negeri 2 Singaraja Tahun Pelajaran 2017/2018.", guna untuk memecahkan masalah yang dihadapi siswa yang bersangkutan.

\section{Metode}

Penelitian Tindakan Kelas (PTK) merupakan jenis penelitian yang mampu menawarkan suatu cara dan prosedur baru untuk memeperbaiki dan meningkatkan kualitas proses belajar-mengajar di kelas mengajar di kelas. Dalam hal ini, cara yang ditawarkan peneliti untuk meningkatkan proses belajarmengajar di kelas adalah penerapan teknik mind maps untuk meningkatkan keterampilan menulis siswa. Penelitian ini tidak hanya dilakukan dalam satu tahap, melainkan dilakukan secara bertahap atau multisiklus. Kegiatan setiap siklus meliputi: refleksi awal, perencanaan tindakan, pelaksanaan tindakan, observasi atau evaluasi, dan refleksi

Dalam melakukan penelitian ini dilakukan kerjasama antara peneliti dengan pendidik bidang studi Bahasa Indonesia kelas VIII-5 SMP Negeri 2 Singaraja sehingga penelitian dapat berjalan dengan lancar dan memperoleh hasil yang maksimal.

Subjek penelitian dalam penelitian ini adalah Subjek dalam penelitian ini adalah siswa kelas VIII5 yang berjumlah 37 orang. Kelas ini dipilih sebagai subjek penelitian berdasarkan hasil observasi awal yang menunjukkan bahwa kemampuan menulis siswa masih rendah dan hampir keseluruhan siswa menemui masalah dalam menulis teks seperti masih kurang dalam mengembangkan ide dan banyak kesalahan ditemukan dalam penggunaan tata bahasa dalam kalimat yang dihasilkan.

Secara terperinci objek yang akan diteliti adalah langkah-langkah pembelajaran menulis dengan menggunakan teknik mind maps, untuk peningkatan kemampuan peserta didik dalam menulis dan respons peserta didik terhadap pembelajaran menulis menggunakan teknik mind maps. Secara umum penelitian ini menggunakan tiga metode pengumpulan data, yaitu (1) metode observasi, Observasi dalam penelitian ini akan peneliti lakukan terhadap kegiatan pendidik dan peserta didik selama pembelajaran berlangsung. Teknik observasi yang dilakukan, adalah kegiatan observasi nonpartisipatif, (2) Metode Tes digunakan untuk untuk mengetahui kemampuan peserta didik dalam memahami konsep dasar dan kemampuan menulis dengan menggunakn teknik mind maps di kelas VIII-5 SMP Negeri 2 Singaraja, (3) Metode angket digunakan dalam pengumpulan data tentang respons peserta didik terhadap penggunaan media film dokumenter dalam menulis teks ceramah.

\section{Hasil dan Pembahasan}

Penelitian ini dilaksanakan dalam dua siklus. Penerapan teknik pembelajaran Mind Mapsdi SMP Negeri 2 Singaraja yang diterapkan pada siswa kelas VIII5 yang berjumalh 37 orang sudah berjalan dengan baik dan sesuai dengan yang direncanakan yaitu untuk meningkatkan kemampuan menulis siswa. Tiap siklus terdiri dari dua kali pertemuan. Pertemuan pertama merupakan proses pembelajaran dengan menerapkan teknik Mind Maps dan pertemuan kedua merupakan tes kemampuan menulis.

Secara umum, penelitian yang telah dilakukan ini dikatakan berhasil dan sudah memenuhi kriteria yang ditetapkan. Namun, pelaksanaan tindakan pada siklus I belum dapat mencapai hasil yang optimal dan belum dapat memenuhi kriteria keberhasilan yang telah ditetapkan. Pada siklus I, rata-rata hasil kemampuan menulis siswa yang diperoleh adalah 65, bila dikonversikan kedalam tabel penialaian Acuan Patokan (PAP) berada pada interval 65-79 yaitu kriteria sedang, selain itu ketuntasan belajar siswa masih belum sesuai dengan yang diharapkan yaitu hanya 49\%, sehingga indikator keberhasilan belum tercapai yakni minimal 75\%. Hal ini disebabkan karena ada beberapa kendala yang dihadapi pada siklus I, seperti kurangnya pemahaman tentang kalimat yang koheren, seperti "Happy birthday mom, i hope mom always healthy and not yeat boring teach i am, wish you all the best.", kemudian penggunaan huruf besar dan kecil seperti "HAPPY BIRTHDAY SISTER, I wish you have long life AND Always Healthy ", ejaan dan juga 
tanda baca seperti penggunaan tanda titik, koma dan tanda seru, selanjutnya kurangnya persiapan peserta didik dalam mengikuti pelajaran, hal ini terlihat ketika guru mengajukan pertanyaan peserta didik masih ragu dalam mengemukakan pendapat, hal ini dapat diatasi dengan menjelaskan kepada peserta didik bahwasannya tidak ada pendapat yang salah atau pun benar, hal yang palin penting adalah mereka harus berani dan percaya diri untuk tampil didepan umum. Banyaknya peserta didik yang kurang disiplin pada saat proses pembelajaran dan guru merasa kurang maksimal dalam memberikan penjelasan dikarenakan kondisi kelas yang kurang kondusif hal ini dapat dilihat ketika proses diskusi di dalam kelompok berlangsung, sebagian besar peserta didik berbicara dengan temannya tentang hal-hal yang tidak berhubungan dengan materi pembelajaran, kemudian membuat keributan dan berjalan kesana-kemari dengan tujuan yang tidak jelas. Beberapa siswa yang kurang aktif juga menjadi kendala pada saat proses pembelajaran hal ini tampak dari beberapa siswa tidak ikut serta bersana teman sekelompoknya ketika berdiskusi dan membuat Mind Maps.

Berdasarkan refleksi siklus I, maka diadakan perbaikan pada siklus II sehingga terjadi peningkatan pada hasil belajar siswa. Melalui beberapa kendala yang ditemui pada siklus I peneliti melakukan perbaikan dan penyempurnaan pada pertemuan siklus II dan hasilnya terjadi peningkatan nilai peserta didik dan respon peserta didik terhadap penggunaan taknik Mind Maps dalam meningkatkan kemampuan menulis mereka.bila dilihat dari persentase ketuntasan secara klasikal sudah mencapai $81 \%$ itu artinya ketuntasan belajar telah tercapai, bila kita bandingkan hasil evaluasi pada siklus I dan siklus II terjadi peningkatan yang cukup signifikan. Hal ini disebabkan oleh kemampuan guru yang sudah maksimal dalam penerapan teknik Mind Maps sehingga peserta didik lebih mudah menuangkan ide dan mengembangkan ide tersebut menjadi sebuah tulisan.

Secara umum pada siklus II tidak ada lagi kendala-kendala yang dihadapi pada siklus I, ini dibuktikan dari hasil kemampuan menulis peserta didik yang sudah mampu mengembangkan ide-ide mereka kedalam kalimat-kalimat yang koheren, ejaan yang benar dan tata bahasa yang tepat. Peserta didik juga telah berperan aktif dalam kegiatan pembelajaran .

Berdasarkan hal tersebut, maka dapat dikatakan bahwa penerapan teknik Mind Maps dapat meningkatkan hasil menulis peserta didik pada kelas VIII5 SMP Negeri 2 Singaraja.

\section{Simpulan Dan Saran}

Berdasarkan uraian di atas dapat disimpulkan bahwa penerapan tenik Mind Maps dapat menerapkan keterampilan menilis peserta didik kelas VIII5 SMP Negeri 2 Singaraja tahun ajaran 2017/2018. Penerapan teknik pembelajaran Mind Maps memiliki dampak yang positif dalam meningkatkan hasil belajar peserta didik khususnya dalam keterampilan menulis.

Berdasarkan kesimpulan yang diperoleh dalam penelitian tindakan kelas ini diajukan saran-saran sebagai berikut: 1) Dalam mengikuti proses pembelajaran hendaknya guru maupun peserta didik menyiapkan diri terlebih dahulu agar hasil pembelajaran menjadi maksimal, 2) dalam melaksanakan proses pembelajaran dikelas, khususnya untuk meningkatkan kemampuan menulis hendaknya guru menggunakan teknik Mind Maps yang sesuai dengan kebutuhan peserta didik, guna menciptakan suasana pembelajaran yang kondusif dan menyenangkan bagi peserta didik, 3) perlu adanya penelitian lebih lanjut, karena penelitian ini hanya dilakukan pada kelas VIII5 SMP Negeri 2 Singaraja.

\section{Daftar Rujukan}

Agung, A. A G. 2005. Metodologi Penelitian Pendidikan, Singaraja: Fakultas Ilmu Pendidikan Institut Keguruan dan Keilmuan Negeri Singaraja

Akhadiah, Sabarti, dkk. 1998. Bahasa Indonesia. Jakarta : Direktorat Jenderal Pendidikan Tinggi.

Aqib, Zainal. 2006. Penelitian Tindakan Kelas, Bandung: Yrama Widya.

Aqib, Zainal. 2013. Model- Model, Media dan Strategi Pembelajaran Kontekstual, ～Bandung: $\quad$ Yrama Widya.

Arifin, Zainal. 2006. Dasar- dasar Evaluasi Pendidikan. Jakarta : PT. Bumi Aksara.

Brown, H.D. 2004. Principle and Classroom Practice.White plains, NY: Longman.

Buzan, Tony. 2009. Mind Map untuk Anak. Jakarta : Gramedia Pustaka Utama. 
Candra, Komang Dian Puspita. 2013 Peningkatan Kemampuan Menulis Karangan Deskripsi Melalui Kombinasi Mind Mapping dan Facebook Community Siswa Kelas X SMAK Anugrah Global Turism Denpasar: Thesis of UNDIKSHA University of Singaraja.

Deporter, Bobbi, dkk. Quantum Teaching, Bandung : PT. Mizan Pustaka.

Dursman, Rijal. 2014. Penerapan Metode Mind Mapping (Peta Pikiran) Untuk Meningkatkan Kemampuan Berpikir Kreatif Matematik Siswa Smp. Infinity Journal, Vol. 3, No.2

Harahap, Sofyan. 2006. Analisis Kritis Atas Laporan Keuangan. Jakarta: Raja Grafindo Persada.

Hikmawati,Citra Roisa. 2013. Penerapan Strategi Mind Map Untuk Peningkatan Hasil Belajar Ips Siswa Kelas V Sekolah Dasar. Jurnal Penelitian Pendidikan Guru Sekolah Dasar, Vol.1, No.2.

Kamus Bahasa Indonesia Luring

Kemendikbud. 2016. Silabus Mata Pelajaran Sekolah Menengah Atas/Madrasah Aliyah/Sekolah Menengah Kejuruan/Madrasah Aliyah Kejuruan (SMA/MA/SMK/MAK). Jakarta: Kemendikbud.

Keraf, Gorys. 1981 Eksposisi dan Deskripsi. Ende: Arnodus.

Mulyana. 2005. Kajian Wacana: Teori, Metode, dan Aplikasi Prinsip “Analisis Wacana:. Yogjakarta: Tirta Wacana.

N, Handayani.2015. The Implementation of Mind Maps in Improving Writing Skill of the Tenth Grade Students of SMA PGRI 2 Denpasar: Thesis of UNDIKSHA University of Singaraja.

Oshima, Alice, and Ann Hogue. Introduction to Academic Writing. US : Addiso-Wesley Publishing Compani, 2007.

Safitri, Dyah. 2016. PENERAPAN METODE MIND MAPPING UNTUK MENINGKATKAN MINAT DAN HASIL BELAJAR IPA SISWA KELAS V SD N BALANGAN. Journal student UNY. Vol. 5, No.3.

Suaidah. 2010. "Upaya Peningkatan keterampilan Menulis Paragraf Deskriptif Dengan Model Pembelajaran Langsung melalui Media Foto Pada Siswa kelas III SD I Garung Lor Kaliwungu Kudus". Skripsi. Unnes.

Tarigan, Henry Guntur. 1994. Menulis Sebagai Salah Satu Keterampilan Berbahasa. Bandung: Angkasa.

Venisari, Rika dkk. 2015. Penerapan Metode Mind Mapping Pada Model Direct Instruction Untuk Meningkatkan Kemampuan Pemecahan Masalah Fisika Siswa Smpn 16 Mataram. Jurnal Pendidikan Fisika dan Teknologi, Vol.1, No.3.

Wiyanto, Asnul. 2004. Terampil Menulis Paragraf, Jakarta : PT. Gramedia.

Yasa, Doantara. 2008. Prsetasi Belajar. (Online). Tersedia: http://ipotes.wordpress.com/2008/05/24/prestasi-belajar

Yosefa, Beni. 2013. Pengaruh Metode Pembelajaran Quantum Teaching Dengan Menggunakanmind Mapping Terhadap Kemampuan Penalaran Matematis Pada Siswa Smp Kelas VIII. Jurnal Pendidikan MIPA. Vol.18, No.2. 